\title{
Spain and the international scientific conferences on polio, 1940s-1960s
}

\author{
María Isabel Porras (*) María José Báguena (**) and Rosa Ballester (***) \\ (*) Departamento de Ciencias Médicas. Facultad de Medicina de Albacete. Universidad \\ Castilla-La Mancha. Marialsabel.Porras@uclm.es \\ (**) Instituto de Historia de la Medicina y de la Ciencia «López Piñero». Universidad de \\ Valencia-CSIC.m.jose.baguena@uv.es \\ $\left.{ }^{(* *}\right)$ Programa Prometeo de la Generalitat Valenciana (Prometeo2009/122). División de \\ Historia de la Ciencia. Universidad Miguel Hernández. rosa.ballester@umh.es
}

Dynamis

[0211-9536] 2010; 30: 91-118
Fecha de recepción: 18 de diciembre de 2009

Fecha de aceptación: 2 de febrero de 2010

SUMMARY: 1.-Introduction. 2.-The difficult international relations for the Franco regime and the polio outbreaks. 3.-The WHO poliomyelitis programme. 3.1.-The contents of the Reports. 4.--International Poliomyelitis Conferences. 4.1.-From epidemiology to vaccination against poliomyelitis. 4.2.-The Spanish presence and its repercussions in the daily and specialized press. 5.-Symposia of the European Association against Poliomyelitis. 5.1.-Spanish participation. 6.-Concluding remarks.

ABSTRACT: The development of international health from a historical point of view has undergone major advances in recent times and constitutes a substantial part of the current agenda for historians of medicine. Within this framework, and focussing on a specific case study (international responses to poliomyelitis outbreaks in the 20th century), we explore the main actions and achievements of agencies such as the WHO and other private and international scientific organizations. Furthermore, this paper seeks to identify the Spanish presence and absence in these activities, their causes and consequences.

PALABRAS CLAVE: Poliomielitis, Comités de expertos de la OMS, Conferencias internacionales sobre polio, Asociación europea frente a la poliomielitis, España, siglo XX.

KEY WORDS: Poliomyelitis, WHO Expert Committees, International Conferences on Polio, European Association against Poliomyelitis, Spain, 20th century. 


\section{Introduction $(*)$}

«For seventy years, polio traumatized the world» ${ }^{1}$. Mark Shell begins his well-known monograph on the disease with these words, with which he sought to give an idea of the feelings of fear of its terrible consequences and the lack of effective remedies to hold it back in the first half of the 20th century and even later. If the problem of polio was a world-wide problem, especially concentrated in western countries, the hopes raised by the appearance of the first effective vaccines were also world-wide. The globalization of preventive activities, including the active immunization of populations against infectious diseases such as poliomyelitis, remains a challenge and an objective to be achieved. The inception of responses to this disease at the international level has yet to be studied in its entirety.

The emergence of poliomyelitis outbreaks in the middle of the twentieth century, with special intensity in developed Western countries, led to a series of scientific meetings of virologists, epidemiologists, paediatricians and public health workers. The most significant activities related to infantile paralysis were the following: a) the birth of the World Polio Congresses in 1948, b) the reports of experts promoted by the World Health Organization, c) the conferences promoted by the European Association against Poliomyelitis, and d) the systematic introduction of monographic sessions in national and international paediatric congresses. One of the main aims of all these activities was to seek international consensus on: technical procedures in laboratory settings for the preparation of poliovirus cultures, the use of different types of vaccines in public health programmes, the design of publicity campaigns, the organization of rehabilitation services for polio patients, and the use of natural physical agents as therapeutic measures, among other issues.

(*) This research was supported by the Spanish Ministry of Science Project (HAR2009-14068-C0201) called «Enfermedades emergentes y comunidades de pacientes» and by the Consejería de Educación-JCCM Project (PII109-0114-0843) entitled "La asistencia antipoliomielítica en España en el siglo XX (los casos de Madrid, Valencia y Castilla-La Mancha): aspectos médicos, sociales y políticos». A preliminary version of this paper was presented at the EAHM Conference on «Global Developments and Local Specificities in the History of Medicine and Health» (Heidelberg, 3-6 September 2009).

1. Shell, Marc. Polio and its aftermath. The paralysis of culture. Cambridge: Harvard U.P; 2005. 
The first years of the 21st century have seen an increase in the historiography devoted to International Health ${ }^{2}$, which includes an in-depth analysis of the birth of some of the main international agencies and the role they played in the transformation observed in the approach to International Health problems from the earliest International Health Conferences in the 19th century up to the creation of the WHO. It has been shown how the figure of the «expert» emerged and acquired importance in the field of International Health. There have also been studies on some of these international agencies in specific countries and their approach to certain health problems ${ }^{3}$ and on their relationships with and influence on the countries' health authorities ${ }^{4}$. However, no analysis has yet been made of the role that these international agencies may have played in the design and implementation of strategies against the epidemic presence of poliomyelitis in Europe after the Second World War. No studies have addressed the Spanish participation (if any) in this fight against the disease, and this is the aim of the present paper ${ }^{5}$. Our initial approach here centres on two aspects. First, an analysis of the main contents of technical reports and international conferences on poliomyelitis between 1948 and 1960 s and, in general terms, the most important strategies and policies in

2. A thought-provoking work on the concepts of «International Health» and «Global Health», and the role played by the WHO in the transition from one to the other, is that of Brown, Theodore M.; Cueto, Marcos; Fee, Elizabeth. The World Health Organization and the transition from «international» to «global» health. In: Bashford, Alison, ed. Medicine at the border. New York: Palgrave Macmillan; 2006, p. 76-94.

3. Among the abundant bibliography, we can mention: Borowy, Iris. Coming to terms with world health. The League of Nations Health Organisations, 1921-1946. Frankfurt am Main: Peter Lang; 2009. Rodríguez-Ocaña, Esteban, ed. The politics of healthy life. An international perspective. Sheffield: EAHMH; 2002. Barona, Josep Lluis. Nutrition and Health. The international context during the interwar crisis. Social History of Medicine. 2008; 21 (1): 87-105. Borowy, Iris. Serological and biological standardisation at the League of Nations Health Organisation, 1921-1939. In: Bonah, Christian et al., eds. Harmonizing drugs. Standards in 20th-century pharmaceutical history. Paris: Editions Glyphe; 2009, p. 203-220.

4. For the Spanish case, see: Rodríguez Ocaña, Esteban. Foreign expertise, political pragmatism and professional elite: The Rockefeller Foundation in Spain, 1919-1939. Stud. Hist. Phil. Bio. \& Biomed. Sci. 2000; 31: 447-461 and Barona, Josep Lluis; Bernabeu-Mestre, Josep. La salud y el Estado. La administración española y el movimiento sanitario internacional (1851-1945). Valencia: PUV; 2008, which is very useful, and includes a comprehensive bibliography on this subject.

5. In other works in progress, we have begun to make a more detailed analysis of any connection between international strategies and those set in motion in Spain to fight against polio. 
the international setting. Second, we attempt to determine the role played in these international events by researchers and other figures involved in Spanish health policies ${ }^{6}$.

This paper is part of a wider study that aims to offer a historical model of how scientific international developments and public health advice - universal in design - were received and implemented (or not implemented) in local settings and how local traditions and circumstances influenced final outcomes ${ }^{7}$. In fact, polio may be seen as an excellent field trial for the application of certain concepts from social sciences, including «policy transfer», a process by which knowledge about policies, administrative arrangements, institutions and ideas in one political setting is used in the development of policies, administrative arrangements, institutions and ideas in another field ${ }^{8}$. The case study will focus on Spain during the period of Franco's dictatorship.

6. A wide range of recent research has focused on international health work, the role played by Spanish figures and institutions, and foreign influences from the Rockefeller Foundation or the LNHO. The following dossier from Dynamis included papers on Spain: Rodríguez-Ocaña, Esteban; Zylberman, Patrick, eds. Improving public health amidst crisis: the interwar years in Europe. Dynamis. 2008; 28: 9-198; the latest synthesis by Barona, Bernabeu-Mestre, n. 4.

7. Some recent papers published on polio epidemics in Spain are as follows: Ballester, Rosa et al. Vivencias personales y experiencias colectivas en torno a la poliomielitis en España (19301975). In: Ortiz, Teresa et al., coord. La experiencia de enfermar en perspectiva histórica. Granada: Universidad de Granada; 2008, p. 313-343; a monographic issue of Asclepio, coordinated by José Martínez Pérez, included the following papers: Báguena, María-José. Estudios epidemiológicos y virológicos sobre la poliomielitis en Valencia (1959-1969). Asclepio. 2009; 61 (1): 39-54; Ballester, Rosa; Porras, María-Isabel. El significado histórico de las encuestas de seroprevalencia como tecnología de laboratorio aplicada a las campañas de inmunización. El caso de la poliomielitis en España. Asclepio. 2009; 61 (1): 55-80; Rodríguez Sánchez, Juan Antonio; Seco Calvo, Jesús. Las campañas de vacunación contra la poliomielitis en España en 1963. Asclepio. 2009; 61 (1): 81-116; Martínez Pérez, José. Presentación: la poliomielitis como modelo para el estudio de la enfermedad en perspectiva histórica. Asclepio. 2009; 61 (1): 7-21; Martínez Pérez, José. Consolidando el modelo médico de discapacidad: sobre la poliomielitis y la constitución de la traumatología y ortopedia como especialidad en España (1930-1950). Asclepio. 2009; 61 (1): 117-142; Báguena, María-José; Porras, MaríaIsabel; Ballester, Rosa. Poliomyelitis in rural and urban Spain: Epidemiological trends, social and scientific responses. In: Barona, Josep Lluis; Andresen, Astri; Cherry, Steve, eds. Making a new countryside? Bern: Peter Lang Verlagsgruppe; 2010, p. 115-134; Rodríguez Sánchez, Juan Antonio et al. A poliomielitis na Peninsula Iberica. Reflexões para a sua compreensão histórica. Coimbra: Universidade da Coimbra (in press).

8. Dolowitz, David P.; Marsh, David. Learning from abroad. The role of policy transfer in contemporary policy-making. Governance. 2000; 13: 5-24. An interesting approach on health is that of Berridge, Virginia. Travelling policies and policy transfer in health since the 1970's: drugs, 
The main historical sources used are the following: 1) Four Technical Reports on Poliomyelitis (1954-1960) by the WHO Committee of Experts; 2) Proceedings of the European Symposia promoted by the European Association against Poliomyelitis (1948-1966); 3) Proceedings of the World Polio Congresses (1948-1960) and 4) Spanish sources: both official and professional documents.

First of all, we need to understand the foreign affairs situation and the global political issues within the international system involving Spain between 1940 and 1970 as well as the role played by polio in these questions. We then need to analyze the framework of health policies related to polio as carried out by international agencies (e.g., the WHO and European Association Against Polio) or by the institutions behind the organization of international congresses on polio.

\section{The difficult international relations of Franco's regime and polio outbreaks}

Apart from some isolated outbreaks before the Spanish Civil War, such as the Madrid epidemic in 1929, polio was contemporary with the Francoist regime. Regarding foreign policy, Spain moved from international isolation and exclusion from the UN and all its organizations, to gradual incorporation from 1950 onwards into agencies such as FAO, UNESCO, WHO, UNICEF and ILO and, finally, to permanent membership of the UN in 1955. However, this «rehabilitation» of the Francoist regime was limited and caused misgivings in Western countries as well as involving tremendous political and economic costs. The polio epidemics paradoxically represented a kind of legitimization of the regime, given its character as a «disease of civilization» ${ }^{9}$,

harm reduction and HIV. Conference of the European Association for the History of Medicine and Health. Heidelberg, 2009 (unpublished).

9. As has recently been pointed out by Axelsson, the prevailing current explanation for the transformation of polio from an uncommon disease to a feared epidemic emphasizes the importance of improvements in hygiene and sanitation. Before the late 19th century, all infants were exposed to the common virus but maternal antibodies that led to lifelong immunity against polio protected them. However, sanitation improvements in some western countries provided a healthier environment and made the virus less common. Consequently fewer infants were exposed to the virus. This increased the proportion of unexposed individuals susceptible to polio later in life. Moreover, improvements in hygiene were most often initiated in areas of relatively high living standards. This made the higher social classes those 
a disease of developed countries where sanitary measures avoided contact of the young with the virus and therefore prevented them from developing immunity. To emphasize the close relationship between development and poliomyelitis that we have just mentioned, Payne launched a new hypothesis that endowed epidemiological data and serological surveys with the value of indicators: as the rates of infant mortality in a given geographical area show a tendency to fall, the incidence and prevalence of polio will increase (the Payne effect). This idea was used as a political argument in some countries and also, particularly, in Spain. Numerous witnesses agreed -in the words of one of the authorities of the time: «as in almost all countries with a high standard of health, in Spain poliomyelitis tends to increase at the same time as infant mortality tends to fall» ${ }^{10}$.

Therefore, in spite of the internal disputes within the different factions of the regime on how to cope with the epidemics and how to transmit health information to the population, efforts were made from the very beginning to attend international forums at which the issues surrounding polio were discussed. The participation of a country with an antidemocratic regime and low international standing in these scientific meetings meant a great deal to the political authorities.

\section{The WHO poliomyelitis programme}

Evidence of interest in poliomyelitis appears in the earliest documents of the international organization. At the First World Health Assembly of 24 July 1948, within the section on «Virus Diseases», a proposal was presented by the French Delegation on Acute Anterior Poliomyelitis, due to the increase in severe forms of polio in numerous countries that «had reached disquieting proportions» ${ }^{11}$. One of the most important issues discussed was that polio should be studied on an international basis, in

most susceptible to the virus. For this reason, polio was considered a disease caused by civilization. Axelsson, Per. Höstens spöke. De svenska polioepidemiernas historia. Stockholm: Carlsson; 2004 [Swedish text with a summary in English], p. 230-238.

10. Bosch Marín, Juan; Bravo, Enrique. Aportación de España a la lucha contra la poliomielitis. In: Aportación española al V Symposium europeo sobre poliomielitis (Madrid, 28-30 September 1958), Madrid: Publicaciones «Al servicio del niño español», Mo de la Gobernación; 1958, p. 45-51.

11. World Health Organisation. First World Health Assembly. Eleventh meeting. 1948, p. 143. 
close collaboration between epidemiologists and laboratory and clinical experts: "The disease lent itself to study by visiting teams. The present approaches were highly expensive for small countries -in particular the use of monkeys for experimental purposes - and the problem could best be studied by international action».

The final resolution of the Health Assembly was the following:

«The appropriate division of the Secretariat shall be immediately instructed to conduct an investigation into poliomyelitis, and recommends:

(1) that such studies shall be based upon the first results achieved by the Brussels and New York Conferences and shall pave the way for the future work of similar conferences, which should receive the support and encouragement of the WHO.

(2) that a report, in the form of a restatement of this important question, shall be submitted to the second Health Assembly» ${ }^{12}$.

The words quoted above clearly show the WHO's interest in poliomyelitis from the very start of its operations in 1948; but it also shows how the research into the disease by the WHO was closely linked to the activities undertaken that year against polio on a world-wide and Europewide basis. As we shall see later, the Brussels and New York Conferences respectively constituted the embryos of the future European Association against Poliomyelitis and the First International Poliomyelitis Conference. Both initiatives were set in motion with the intention of fighting against poliomyelitis, which emerged as an important public health issue in the Western world after the Second World War. The extent to which the WHO committed itself to cooperate with and support both initiatives in its First World Health Assembly is also clear.

From 1953 onwards, the WHO also included polio among its own priorities, probably because of the weight in the Organization of severely affected countries that were investing substantial human and economic resources in research, as was the case of the USA and some European countries. The Third World Health Assembly stressed the desirability of international guidance on measures to be taken to prevent the spread of poliomyelitis. It recommended the establishment of a committee of experts to co-ordinate research, with a view to obtaining the information necessary 
to specify effective preventive measures. The first session of the Committee was held in Rome from 14 to 19 September 1953, immediately after the Sixth International Congress of Microbiology.

The specific means by which the WHO became involved in the question of polio was thus the common way to deal with this type of problem. For advice on more technical questions, the Secretariat headquarters appointed a panel of experts, from which were selected Committees of Experts to recommend policies ${ }^{13}$. Between 1953 and 1960 the executive board, whose functions included the setting up of these Committees of Experts ${ }^{14}$, appointed several specific committees to deal with the subject of polio. The importance given to the question was further demonstrated when the meetings of the committees were published in the form of reports, sanctioned and approved by the General Assembly; this only happened in cases which were considered to be highly important and required international diffusion. These reports were published either partially or in their entirety. In the case of polio, all reports were published in their entirety.

The Committees of Experts were (and still are) the key to the workings of the Organization. Their purpose was to give technical advice on particular questions. The reports, of which four were published between 1953 and 1960, did not necessarily express the view of the Organization, but they were an essential tool in forming policies and preparing programmes.

Individual members were appointed on their own merit, not as representatives of governments, institutions or associations, although efforts were made to ensure some geographical spread. The criterion of competence rather than nationality led to a kind of trans-national community of experts ${ }^{15}$ with roots in the international public health movements of organizations founded prior to the setting up of the WHO, such as the Office International d'Hygiène Publique (OIHP).

Who were the members of the Expert Committee on Polio? Two members of the Secretariat were key figures in the early history of the WHO:

13. Roemer, Milton I. Internationalism in medicine and public health. In: Bynum, William F.; Porter, Roy, eds. Encyclopaedia of the History of Medicine. London: Routledge; 1993, p. 1427-1429.

14. World Health Organisation. Constitution of the World Health Organisation. Chapter VIII, art. 38-40. 1946.

15. Solomon, Susan Gross; Murard, Lion; Zylberman, Patrick. Shifting boundaries of public health. New York: University of Rochester Press; 2008, p. 6-8. 
W. Bonne, director of the Division of Communicable Diseases and A. Payne, professor and chairman of the Department of Epidemiology and Public Health, Yale University School of Medicine, formerly Chief Medical Officer for virus diseases. The other experts on the committees varied over time. The total number of committee members fluctuated between 10 and 15 . Of the permanent members, four appeared in each and every one of the Reports. Three were from the field of experimental laboratory research: Sven Gard from Sweden, John Gear from South Africa, and the Head of the Virus Service of the Institut Pasteur, Pierre Lépine, probably the most important virologist of his time. The fourth, the professor of preventive medicine at the Yale University School of Medicine, John Paul, was a key figure in the history of polio and author of the first history of the disease ${ }^{16}$; he acted as chairman. The remaining members depended on the content of each report and on the importance of a particular issue at any given time. For instance, the epidemiologist Thomas Francis ${ }^{17}$ appeared in the First Report of 1954, at a time when preparations were in hand for the clinical trials of the Salk vaccine, carried out under his direction in April 1955. Likewise, Albert Sabin, professor of paediatric research at the University of Cincinnati and creator of the oral polio vaccine (OPV), was invited to take part in the Reports of 1956 and 1958 when the scientific forums were discussing anti-polio vaccines and research on inactivated vaccines and attenuated live virus vaccines.

\subsection{The contents of the Reports}

Between the first report of the Expert Committee (1954), which dealt with the general aspects of the disease (causal agents, acute clinical symptoms, laboratory methods and general and non-specific preventive measures) ${ }^{18}$ and the second report in $1958^{19}$, a series of important advances in research made it necessary to publish a monograph on the new vaccination proce-

\footnotetext{
16. Paul, John. A history of poliomyelitis. New Haven: Yale University Press; 1971.

17. Monto, Arnol. Francis trial on inactivated poliomyelitis vaccine background and lessons for today. Epidemiological neviews. 1999; 21(1): 7-23..

18. World Health Organisation. Expert Committee on Poliomyelitis. First Report. Geneva: World Health Organisation [Technical Reports, no. 81]; 1954.

019. World Health Organisation. Expert Committee on Poliomyelitis. Second Report. Geneva: World Health Organisation [Technical Reports, no. 145]; 1958.
} 
dures. Above all, there was exceptional interest in the mass media about the widespread clinical trials carried out by the epidemiologist Thomas Francis with Jonas Salk's injected polio vaccine (IPV) ${ }^{20}$. Its success in the USA encouraged other research teams from different countries to prepare vaccines with inactivated viruses.

However, the committee believed that the general prophylactic measures (except active immunization with convalescents' serum) listed in the first report retained all their value. These measures included the following: notification of polio cases, isolation and care of the patients, protection of families and collectives exposed to the infection, and appraisal of the risk of paralysis as a consequence of both vaccinations and surgical procedures. The production of vaccines continued to pose problems and difficulties that required rigorous and constant surveillance of the preparation procedures.

The decision to undertake or intensify a vaccination campaign was the competence of the national authorities, who best understood the importance of poliomyelitis in comparison with other urgent public health problems in each country. Polio vaccination might be more suitable in some countries than in others. It was necessary to carry out, in each country, an in-depth study of the background of the problem and to attempt to foresee its evolution over the next ten years. The first signs of the imminence of an outbreak were as follows: a) decrease in infant mortality to below 75 deaths per 1,000 children and 2) the appearance of polio cases not only among breast-fed babies but also in older children. When at least $20 \%$ of victims were over ten years of age, an intensification of the disease could be expected.

On the other hand, it was considered of great importance to keep full records that provided information on doses and dates of inoculation plus a statement on possible adverse reactions.

The fourth and final meeting of the Expert Committee during this period took place in Washington in June $1960^{21}$. It was held in a mood of optimism as a result of the potential of oral polio vaccine (OPV) for the mass immunization of the population and the effectiveness of the vaccine,

20. World Health Organisation. Expert Committee on Poliomyelitis. The vaccination against polio. Preliminary exam. Geneva: World Health Organisation [Technical Reports, no. 101]; 1956.

21. World Health Organisation. Expert Committee on Poliomyelitis. Third Report. Geneva: World Health Organisation [Technical Reports, n. 203]; 1960. 
which caused a sharp fall in morbidity rates in countries in which it was used. In the majority of countries, it was decided to immunize with the oral vaccine, since it was cheaper, easier to administer and allowed collective immunity to be given to the population.

Spain played no part at all in any of the four reports. There was not a single Spanish representative on the committees and subcommittees, not even as «temporary adviser», and there is no information on epidemiological data or any activities being carried out. This information was available for a large number of countries, some geographically smaller and with smaller populations than Spain. However, this is consistent with the Franco regime's reluctance to admit the presence of disease and the circumstances of isolation during the early years of the dictatorship. It should be borne in mind that Spain was excluded from the WHO until 1951. Although this exclusion may be explained by the regime's political ideology, we agree with Barona and Bernabeu in also relating it to the setbacks suffered by Spanish public health after the Civil War, due to the exile and repression of health professionals ${ }^{22}$. In fact, two of the exiled republicans - Marcelino Pascua (1897-1977) and Santiago Ruesta Marco (1899-1960) - formed part of the WHO as experts and played a significant role in the organization. Marcelino Pascua arrived in the organisation in 1948 as a health statistician and retired in 1966 after almost ten years as consultant to the Director General of $\mathrm{WHO}^{23}$. Nevertheless, as we shall show, it would not be until 1958 that Florencio Pérez Gallardo (1917-2006), director of the Laboratory of Virology, National Health School (Madrid), represented the WHO as delegate of the European Regional Office in the V Symposium of the European Association against Poliomyelitis.

What repercussions did the warnings and recommendations of the WHO have in Spain? We are probably still not in a position to make a detailed report, but we see a health administration with significant internal disputes that undoubtedly delayed, for instance, the implementation of vaccination campaigns and did not help basic research ${ }^{24}$. The economic hardship of the early years of the Franco regime also contributed to this situation and to

\footnotetext{
22. Barona; Bernabeu-Mestre, n. 4, p. 295.

23. Barona; Bernabeu-Mestre, n. 4, p. 300-301

24. For what happened in the serological surveys, see: Ballester; Porras, 2009, n. 7.
} 
the delayed implementation of specialized care for poliomyelitis patients ${ }^{25}$. However, eminent figures and groups were active in the country, and Spain did take part in another type of event, as we shall discuss below.

\section{International Poliomyelitis Conferences}

\subsection{From epidemiology to vaccination against poliomyelitis}

The National Foundation for Infantile Paralysis celebrated its tenth anniversary by funding the First International Poliomyelitis Conference in New York in 1948. The objective was to coordinate and assess the progress made by medicine in the study of infantile paralysis during the previous decade. The other four conferences took place in Copenhagen (1951), Rome (1954), Geneva (1957) and again in Copenhagen (1960). They were all funded by the above-mentioned North American organization, under whose auspices the International Poliomyelitis Congress was set up. It was entrusted with the practical arrangements of the Conferences and was headed by Basil O'Connor, president of the National Foundation. The minutes were published by J.B. Lippincott ${ }^{26}$. The work carried out by the North American organization - the National Foundation for Infantile Paralysis - may be considered partly comparable to that done by the Rockefeller Foundation (RF), but solely in reference to poliomyelitis and rather more limited in time. We could therefore say, as some authors have done in interpreting the role of the major international agencies - notably the RF and the League of Nations Health Organization ( $\mathrm{LNHO}$ ) - , that this organization carried out a simple

25. Báguena; Porras; Ballester, n. 7; Porras, Maria Isabel; Ballester, Rosa. The incorporation of medical Technology for the treatment of the acute stage of poliomyelitis in Spain (1940-1965). ESSHC (Lisbon, 2008).

26. Poliomyelitis. Papers and discussions at the First International Poliomyelitis Conference. Philadelphia: J.B. Lippincott Company; 1949; Poliomyelitis. Papers and discussions presented at the Second International Poliomyelitis Conference. Philadelphia: J.B. Lippincott Company; 1952; Poliomyelitis. Papers and discussions presented at the Third International Poliomyelitis Conference. Philadelphia: J.B. Lippincott Company; 1955; Poliomyelitis. Papers and discussions presented at the Fourth International Poliomyelitis Conference. Philadelphia: J.B. Lippincott Company; 1958; Poliomyelitis. Papers and discussions presented at the Fifth International Poliomyelitis Conference. Philadelphia: J.B. Lippincott Company; 1961. 
colonial strategy linked to the interest of American industry ${ }^{27}$. However, as in the case of the RF and the LNHO, we can add another interpretation which also includes the significant benefits ${ }^{28}$ brought by the experience of polio that this organisation acquired and the resources that it could bring for a more effective fight against the epidemics of poliomyelitis and their after-effects in Europe. Indeed, apart from the first conference, all of the rest were held in European cities that were important both as victims of epidemic polio outbreaks and for their traditional position in the field of International Health.

There was a gradual change in the subjects covered in the different conferences. The first (1948) began its sessions with a talk by Albert Sabin 29 underlining the importance of polio as a world-wide problem. He described the epidemiological patterns of the disease in different parts of the world, and provided data on the outbreaks in both rural and urban communities in the United States, Sweden and Denmark as well as in different racial groups. He emphasized the increase in age of polio victims as one of the main results of his research. The pathogenesis, treatment of polio and rehabilitation issues were also addressed. In a session on immunology and chemotherapy, J. Paul presented the results of his research on the different strains of the polio virus, which proved to be fundamental in the subsequent development of an anti-polio vaccination ${ }^{30}$. In the final session, delegates from twenty-eight countries (which did not include Spain ${ }^{31}$ ) gave reports on the epidemiological characteristics of polio and the treatments applied in their setting ${ }^{32}$.

In the second Conference (1951), the session that aroused the liveliest debate with the greatest number of contributors was devoted to the diffe-

27. As Barona and Bernabeu have pointed out, this interpretation arises from a very simplistic approach to the complex historical reality of the inter-war period. Barona; Bernabeu-Mestre, n. 4, p. 166.

28. On the benefits provide by the RF and the LNHO, according to Barona and Bernabeu, see: Barona; Bernabeu-Mestre, n. 4, p. 166 et sea.

29. Sabin, Albert, B. Epidemiological patterns of poliomyelitis in different parts of the world. In: Poliomyelitis, 1949, n. 26, p. 3-33.

30. Paul, John R. Immunological types of poliomyelitis viruses. In: Poliomyelitis, 1949, n. 26, p. 271275.

31. On the absence of Spain, we refer to our comments on the WHO.

32. Poliomyelitis throughout the world. In: Poliomyelitis, 1949, n. 26, p. 325-354. 
rential diagnosis of acute poliomyelitis ${ }^{33}$. In this session, Robert Debré (1882-1978), one of the founders of modern paediatrics and President of the French Institut National d'Hygiène, and Stéphane Thieffry concentrated on paralytic polio, while Jordi Casals presented a specific complement fixation test for the disease, and Jonas Salk gave an immunological classification of the polio virus. There were numerous sessions on the treatment and ecology of the disease, as well as on virology, with contributions on the interactions of the virus with host cells, immunity in polio, the viruses of the Coxsackie group and an interesting intervention by J. Enders on the growth of the polio virus in human embryo tissue ${ }^{34}$.

At the third Conference (1954), studies on physical medicine, rehabilitation, orthopaedic treatment and the acute phase of polio shared the floor with those focused on the social aspects of the disease ${ }^{35}$. The latter, centred on Italy, the Scandinavian countries and the United States, presented the need for the work rehabilitation of polio victims suffering from the after-effects of the disease. However, the greatest expectation was aroused by the report of J. Salk on the results of his vaccine and A. Sabin's contribution on new inactivated strains of the virus for immunization in a session opened by Pierre Lépine, head of the Virus Service of the Institut Pasteur, who presented the current epidemiological situation of polio ${ }^{36}$. J. Enders also attended this congress with his latest work on the development of the poliovirus in tissue cultures ${ }^{37}$, presented in closed session with the projection of a film on the production of the polio virus ${ }^{38}$.

At the fourth Conference (1957), there were numerous papers on the study of the polio virus and on the different vaccines available, both those prepared from deactivated virus (such as those of J. Salk and D. Bodian), and those using attenuated virus, most notably those of A. Sabin, H. Koprowski and A. Payne. Extensive time was also devoted to the respiratory

33. Debré, Robert et al. Differential diagnosis in acute poliomyelitis. In: Poliomyelitis, 1952, n. 26, p. 157-211.

34. Enders, John F. The multiplication and properties of poliomyelitis viruses in cultures on human tissue. In: Poliomyelitis, 1952, n. 26, p. 33-43.

35. Cramarossa, Saladino et al. Social aspects of poliomyelitis. In: Poliomyelitis, 1955, n. 26, p. 123.

36. Lépine, Pierre R. Infection and immunity in poliomyelitis. In: Poliomyelitis, 1955, n. 26, p. 127217.

37. Enders, John F. Developments in tissue culture. In: Poliomyelitis, 1955, n. 26, p. 219-273.

38. This film was produced by Connaught Laboratories of Toronto (Canada). 
problems of polio sufferers and their care in special centres or at home, as well as the treatment of severe forms of polio. These interventions made clear a new challenge, stated by James Wilson in the introduction to this session: it was not enough to save the patient's life; the life saved must be as useful as possible ${ }^{39}$.

The fifth Conference (1960) did not include any reports from the official delegates on the polio situation of their respective countries and was given over entirely to the study of the polio virus and the vaccines manufactured as a result. Papers on the former dealt with its morphology, chemical structure and mutations and with the immunological reactions it causes. Results were reported on the application of vaccines with deactivated viruses created in the United States, Canada, Denmark and Norway; the highlight was Salk's speech on the duration of the immunity provided by his vaccine ${ }^{40}$. The results achieved with vaccines produced from attenuated virus were also presented, including those of Sabin in Colombia, Costa Rica, Nicaragua and the Soviet Union ${ }^{41}$. The production of antibodies with this type of vaccine led to the participation, among others, of H. Koprowski, H. Cox and Sabin himself ${ }^{42}$, while the effect of attenuated virus vaccines on the population received the attention, among others, of J. Paul ${ }^{43}$, whose participation was very active throughout these congresses.

\subsection{The Spanish presence and its repercussions in the daily and specialized press}

There was Spanish representation in all but the first Conference (1948). This Spanish absence went unremarked in the daily press and in the medical journals we have consulted. There was an official delegation at the

\footnotetext{
39. Wilson, James L. Care of patients severely stricken by poliomyelitis. Introduction. In: Poliomyelitis, 1958, n. 26, p. 470-471.

40. Salk, Jonas E. Persistence of immunity following administration of Formalin-Treated Poliovirus vaccine. In: Poliomyelitis, 1961, n. 26, p. 157-175.

41. Horwitz, Abraham et al. Attenuated virus vaccine: Experience in field safety and efficacy. In: Poliomyelitis, 1961, n. 26, p. 221-278.

42. Contreras, Guillermo et al. Attenuated virus vaccine: Antibody response. In: Poliomyelitis, 1961, n. 26, p. 279-355.

43. Paul, John R. The spread of attenuated polioviruses among household contacts. In: Poliomyelitis, 1961, n. 26, p. 359-367.
} 
second Conference (1951), comprising Florencio Pérez Gallardo (19172006), director of the Virology Laboratory of the National School of Health and Darío Fernández Iruegas, professor of paediatrics in the Faculty of Medicine of Madrid and director of the Hospital-Asylum of San Rafael (Madrid). Dario Fernández presented a report on the situation of polio in Spain ${ }^{44}$. He reported on the 1929 epidemic in Madrid, from where the epidemic extended throughout the country. The number of cases did not exceed six per 100,000 inhabitants in any province, and its geographical distribution remained practically identical every year from 1930 to 1950. The behaviour of the disease in Spain contrasted with that observed in the rest of Europe. The Spanish epidemic outbreak in 1929 had no equivalent in other countries of the continent, where the disease increased between 1935 and 1940 while it became less frequent in Spain. In 1942, the decrease in the United States and Europe coincided with a rise and subsequent fall in Spain, where epidemic outbreaks were detected eight years later in Madrid, Valencia, Santander and Pontevedra. The main conclusion of the report was that in Spain, as in the rest of the world, polio was tending to increase. On this occasion, the daily press did cover the attendance of the Spanish delegates at the Copenhagen conference and emphasized the announcement there of the possible imminent discovery of effective remedies to combat the disease ${ }^{45}$.

The third Conference (1954) was attended by several Spanish physicians. Apparently there was no official delegation, although Juan Bosch Marín, head of the Child Health Service of the Dirección General de Sanidad (General Health Department), was present. Francisco Barnosell Nicolau, orthopaedic surgeon, director of the Institute of Corrective Medicine of Barcelona and head of the Central Rehabilitation Service of the Hospital Clínico (Barcelona), gave a showing of the film "Physiotherapy and re-education in polio sequela". Bosch Marín intervened in the discussion on respiratory disorders in polio due to bulbar involvement in polio and outlined his favourable experience

44. Fernández Iruegas, Darío. Reports of the official delegates. Spain. In: Poliomyelitis, 1952, n. 26, p. 149-150.

45. La lucha contra la parálisis infantil. Las Provincias. 5 Sep. 1951: 4; La lucha contra la parálisis infantil. La Vanguardia. 6 Sep. 1951: 1; Congreso Internacional de Poliomielitis en Copenhague. Levante. 8 Sep. 1951: 1. 
with the use of respiratory tanks, the only devices available in Spain, as he stressed, for the treatment of respiratory complications ${ }^{46}$.

In the discussion following the section on physical medicine and rehabilitation in polio, mention was made of «A critical examination of the Kenny method in the treatment of polio» by Vicente Sanchis Olmos (1911-1963), Head of the Orthopaedic and Traumatology Service of the Hospital de la Cruz Roja (Madrid) and member of the National Institute of Re-education of Invalids in Madrid. His paper studied two of the factors that might aggravate the acute phase of polio and were under debate: irradiation of the medulla with short-wave and with X-rays ${ }^{47}$.

The congress was also attended by: the neurologist Ramón Sales Vázquez (1971), Chief of the polio service of the Clinical Hospital of Barcelona; Francisco Barberá Carré, specialist in functional re-education; the paediatrician Darío Fernández Iruegas; and Víctor Meana Negrete, director of the National Maritime Sanatorium of Pedrosa (Santander) and director of the Hospital-Asylum of San Rafael (Madrid) on the death of Fernández Iruegas 48 .

The daily press reflected the results of the first vaccinations against polio carried out in the United States and announced at this third conference ${ }^{49}$. La Vanguardia gave it full coverage from its inauguration and, considering the different contributions, concluded that there were grounds for cautious optimism in the battle against polio, identified as «the disease of civilization ${ }^{50}$, because $«$ it increased at the same time as living standards» ${ }^{51}$. It

46. Bosch Marín, Juan. Acute medical care in Poliomyelitis. Discussion. In: Poliomyelitis, 1955, n. 26, p. 105.

47. Rosen, Sophus von. Some views on rehabilitation. In: Poliomyelitis, 1955, n. 26, p. 358; p. 362; p. 363.

48. He organized a Rehabilitation Centre in the National Maritime Sanatorium of Pedrosa (Santander) under the auspices of the Health fight against disability (Lucha sanitaria contra la invalidez). In the same city, he headed the orthopedic clinic of the Infanta Santa Clotilde, belonging to the Hermanos de San Juan de Dios.

49. III Conferencia Internacional de Poliomielitis en Roma. La Vanguardia. 7 Sep. 1954: 1; Roma está especializada en congresos internacionales. Levante. 11 Sep. 1954: 3.

50. Congresos internacionales de gran interés. La Vanguardia. 10 Sep. 1954: 10.

51. La lucha contra la parálisis infantil. La Vanguardia. 14 Sep. 1954: 11. This article highlighted the use in the congress of the latest technological advances, which had enabled the presentation in the last session of a photograph of the poliovirus taken with an electronic microscope, transmitted by television and shown on «a large cinema screen». 
highlighted the Spanish participation and stressed the importance of the success obtained with the vaccine developed by Salk.

There was an official Spanish delegation at the fourth Conference (1957), led by Bosch Marín, vice-president of the European Association against Poliomyelitis. The scientific delegation was made up of various paediatricians: Ciriaco Laguna Serrano (1905-1990), professor of paediatrics from Madrid; Antonio Galdó Villegas, professor of paediatrics from Granada; Manuel Cruz Hernández, professor of paediatrics from Cádiz; Manuel de la Iglesia and Espadaler from the department of paediatrics in Barcelona; and Darío Fernández Iruegas, as well as orthopaedic surgeons Francisco Barnosell and Esteve de Miguel, functional re-education specialist Francisco Barberá Carré; neurologist Ramón Sales Vázquez, Director of the Department of Infantile Paralysis of the Hospital Clínico of Barcelona, who also represented the Medical Faculty of Barcelona; and José María Sala Ginabreda, from the Municipal Hospital of Infectious Diseases in Barcelona ${ }^{52}$.

Bosch Marín, in his report on the situation in Spain, emphasized that the Payne phenomenon was taking place, with an increased incidence of polio in parallel with the improved state of health. There had been more than 1500 cases annually since 1950 , and $91 \%$ of cases were in children under five years old; the morbidity was virtually identical between small towns and cities. He also mentioned the existence of 150 artificial respirators, stressed the growing interest in disability as an after-effect of the disease, and reported the recent creation of the National Rehabilitation Board ${ }^{53}$. For his part, the orthopaedic surgeon Esteve de Miguel took part in the scientific exhibition of the Conference with a study on precautions against the shortening of the lower limbs in paralysed patients ${ }^{54}$.

This conference in Geneva received the greatest coverage in the Spanish press yet. It was particularly important because of the reports on the

52. Also present were doctors Quintana, Olaizola, Antonin, Tellería, Roquerro and Martínez.

53. Bosch Marín's speech was not included in the publication of the minutes of this fourth conference, probably because the text of his report was not sent to the editors, as indicated at the end of the published reports: Reports of Official Delegates. In: Poliomyelitis, 1958, n. 26, p. 63. We have a record of this report in the summary of the congress prepared by two of the Spanish participants: Cruz Hernández, Manuel. La cuarta Conferencia Internacional sobre la poliomielitis. Acta Pediátrica Española. 1957; 15 (177): 727-738 and De la Iglesia, Manuel. La cuarta Conferencia Internacional sobre la poliomielitis. Archivos de Pediatría. 1957; 8 (45): 241-246.

54. Cruz Hernández, n. 53, p. 737. 
fifty million vaccinations in the United States and on the immunization campaigns conducted in Scandinavian countries ${ }^{55}$. Bosch Marín attracted the attention of the press by announcing that the next assembly of the European Association was to be held in Madrid in $1958^{56}$, and they reported his statements on his return from the congress to the effect that «Polio has never been a health problem in Spain», although at the time there was a noted tendency for it to increase, as it had in the first three decades of the century in all developed countries; he therefore recommended vaccination in the future, in line with the other participants in the conference ${ }^{57}$.

The fifth Conference (1960) was attended by doctors from the National Hospital for Infectious Diseases (Madrid): Juan Figueroa Egea, clinical head, and Juan Torres Gost, director of the hospital; specialists in re-education and rehabilitation, Argüelles from Madrid, F. Barberá Carré and Luis Portal Llamedo from Barcelona; the neurologist Sales Vázquez, and Vicente Sanchis-Bayarri, assistant professor of Public Hygiene and Microbiology from Valencia ${ }^{58}$. The latter, in his account of the conference, indicated that all of the participants had been invited to take part by the Organizing Committee ${ }^{59}$. The publication reporting the minutes of the congress included no contribution from the Spanish participants ${ }^{60}$.

Among those attending the conferences, the evidence shows that among the Spanish representatives there was a majority of paediatricians, orthopaedic surgeons, rehabilitation experts and neurologists. Francisco Pérez Gallardo, director of the Virology Laboratory of the National School of Health (Madrid) and Sanchis-Bayarri, author of pioneering studies in Spain on the polio virus were only present at the second and fifth Conferences, respectively ${ }^{61}$. The presence of Sanchis-Bayarri indicated a change in the trend of the subjects covered at the conferences: studies on clinical practice, diagnosis and surgical and orthopaedic treatment lost ground

55. Conferencia internacional sobre la poliomielitis en Ginebra. La Vanguardia. 2 Jul. 1957: 14; Españoles en el Congreso Internacional de poliomielitis en Ginebra. Las Provincias. 9 Jul. 1957: 4; Congreso Internacional de la poliomielitis en Ginebra. Levante. 9 Jul. 1957: 5.

56. España en el Congreso Internacional de poliomielitis en Ginebra. La Vanguardia. 9 July 1957: 4.

57. Declaración del Dr. Bosch Marín. Las Provincias. 18 July 1957: 13.

58. Doctors Espalder and Foz were also present.

59. Sanchis-Bayarri Vaillant, Vicente. V Conferencia sobre poliomielitis. Medicina Española. 1960; 44: 338-345.

60. There was no news of the conference in the press we have consulted.

61. Báguena, n. 7. 
to contributions on the virus and on the different vaccines available to prevent the disease. For his part, the presence of Pérez Gallardo in 1951, just when Spain was admitted to the WHO, could be interpreted as a clear manoeuvre to give political validity to Franco's regime, represented by a competent professional linked to lines of international epidemiological research in this field.

\section{Symposia of the European Association against Poliomyelitis}

Following an initiative of the Belgian Professor L. Laruelle, an assembly of epidemiologists, clinicians and researchers was brought together in Brussels in 1948, constituting the core of a new group that became the European Association against Poliomyelitis, set up in 1951 in Brussels. Its first Symposium was held in April 1953 in the Serum Institute of Copenhagen ${ }^{62}$ and was dedicated to the epidemic in this city from July to December of the previous year. This epidemic was the worst that Denmark had had ever suffered; its importance was due not only to the number of people affected (including paralytic forms) but also to the severity of the respiratory problems. These required the generalized use of tracheotomy, combined with some methods of controlled respiration derived from anaesthesia ${ }^{63}$. Between 1953 and 1966, eleven Symposia were held in different European cities, every one or two years. The first and second Symposium reports were published with the support of the Archives belges de médecine sociale, hygiène, médecine du travail et médecine légale ${ }^{64}$. The first President was P. Lépine (Paris), head of the Virus Service of the Institut Pasteur. The other members of the permanent committee of the European Association against Poliomyelitis were professors and doctors from Copenhagen (Prof. Lassen), Berne (Dr. Vollenweider), London (Dr. Bradley, Ministry of Health), Utrecht (Dr. Hemmes), and Brussels (Dr. P. Recht). Presidents of Honour were Professor Kling (Sweden) and Dr.

62. This was the National Serum Institute, under the Danish Ministry of Health. This institute acted as the central laboratory of the League of Nations Health Organisation in the process of standardization during the inter-war period. Barona; Bernabeu-Mestre, n. 4, p. 159.

63. This treatment was used as a substitute for iron lungs. Association Européenne contre la poliomyélite. I Symposium Européen de la Poliomyélite. Copenhague, avril 1953. Bruxelles: Éditions Acta Medica Belgica; 1954, p. 7-9.

64. Publication related to the Ministère de la Santé Publique et de la famille (1946-1981). 
L. Laruelle (Belgium). According to Lépine, the studies and theories of Kling played an important role at the beginning of the renewal of concepts of epidemiological and experimental data on polio, and Dr. Laruelle's audacious initiatives were the key to finally achieving the creation of the European Association against Poliomyelitis ${ }^{65}$.

We can observe a trend in the selection of the topics covered at the different Symposia. The first (1953), devoted to the severe Copenhagen polio epidemic and active and passive methods of immunization, also provided a bibliography published in English, French and German. The number of participants in the first and second Symposia was very limited in comparison to the attendance at the following Symposia. The importance and severity of this epidemic meant that the main topics were the description of the epidemic and its different epidemiological, clinical and therapeutic aspects, with special mention of the above-mentioned approaches to solving the severe respiratory difficulties. A lack of knowledge on some key features of polio and the ways to combating it became clear during the discussions on the Copenhagen epidemic; the need was also revealed for a closer study of the problem in an organised, scientific and standardised manner to permit comparisons of date from different countries. The examination of active and passive immunization methods made by professor P. Lépine of the Institut Pasteur of Paris demonstrated the development of passive prophylactic measures from 1910 onwards and the importance of the introduction of gamma-globulin in 1950 by the American, William Hammon. As Lépine explained, he and his collaborators had used it extensively under the auspices of the National Foundation for Infantile Paralysis, and had noted the success of this method ${ }^{66}$. He reviewed the history of the active prevention of polio, mentioning the three possible methods for obtaining the vaccine; he acknowledged that some technical problems remained, but he was confident that a vaccine could be available in the near future ${ }^{67}$. However, after the interesting debate that followed Lépine's presentation, the European Association concluded that «it would be premature to formulate any opinion regarding the value and practicability of vaccination against poliomyelitis in

65. European Association against Poliomyelitis. III Symposium, Zürich, 29-30 September 1955. The problem of anti-poliomyelitis vaccinations. Brussels: EAP; 1956, p. 3.

66. Association Européenne contre la poliomyélite, n. 63, p. 54-55.

67. Association Européenne contre la poliomyélite, n. 63, p. 60. 
the present state of knowledge», and it recommended «that member countries should carry out, within the limits of their means, scientific and well controlled trials of these methods» ${ }^{6}$.

The topic of the second Symposium (1954) was hospitalization from all points of view and perspectives, with special attention to treatment in the acute stage. For the first time, there was a WHO delegate, Dr. A. Payne, from the Division of Communicable Disease Services ${ }^{69}$. There were four sessions dedicated to examining the different problems related to the hospitalization of polio patients in the acute stage. A total of eight points were discussed: the characteristics of the poliomyelitis hospital centre and its place in the general hospital organization of each country; technical and material equipment; medical staff, nurses and auxiliaries; the functioning of the service; hospital epidemiology; precautions in the case of an epidemic or exceptional circumstances; social services for polio patients, and medical and social links; and the role of the hospital as a centre for scientific research and specialized training ${ }^{70}$. One of the key points was whether polio patients in the acute stage should be hospitalized in a special hospital for polio victims or in a specialized department of a general hospital. The latter course was supported by Robert Debré, president of the French Institut National d'Hygiène, creator of the University hospitals and responsible for French hospital reform, X. Leclanche and S. Thierry ${ }^{71}$.

At the third Symposium (September of 1955), which was once again attended by Dr. Payne, the WHO delegate ${ }^{72}$, the question of anti-poliomyelitis vaccinations was raised for the first time. The early vaccination experiences of some European countries (Sweden, Denmark, Germany...) were presented, as well as the results of the first studies on the degree of anti-poliomyelitis immunity of Italian and Belgian populations ${ }^{73}$. The brilliant and fascinating speech by Lépine (Le problème des vaccinations antipoliomyélitiques et l'appréciation du niveau d'immunité des populations)

\footnotetext{
68. Association Européenne contre la poliomyélite, n. 63, p. 64.

69. Association Européenne contre la poliomyélite. L'hospitalisation des poliomyélitiques à la phase aiguë. Recueil des travaux du II Symposium Européen de la Poliomyélite organisé à Paris le 8 et 9 avril 1954. Bruxelles: Éditions Acta Medica Belgica; 1955, p. 5.

70. Association Européenne contre la poliomyélite, n. 69, p. 5-6.

71. Association Européenne contre la poliomyélite, n. 69, p. 12.

72. Dr. Payne was the only WHO representative at the majority of these Symposia.

73. European Association against poliomyeliis. Third Symposium, Zurich, 29-30 September 1955. The problem of anti-poliomyelitis vaccinations. Bruselles: EAP; 1956, p. 7-77.
} 
provided the general framework for the presentation of particular European cases ${ }^{74}$. The great importance acquired by vaccination and the subsequent debate led to the constitution of a limited commission to set down conclusions derived from the different opinions ${ }^{75}$. This symposium was also devoted to the analysis of the different treatments of poliomyelitis in the acute stage, which were studied in all their complexity (the prevention of deformities ${ }^{76}$, role of aggravating factors, weaning from the iron lung and mechanical breathing apparatus).

At the fourth Congress (1956), the main topics were: anti-polio vaccination, outbreaks resembling polio, re-education in walking and the organisation of a re-education centre, which for the first time played a central role. The great majority of the sessions were devoted to this subject, and the results of the Symposium, which now had some 200 delegates from 22 different countries. were compiled in a book entitled «Re-education in walking after poliomyelitis», ${ }^{77}$. These same topics were the key points of the fifth Symposium (1958), although polio vaccination regained its prominence ${ }^{78}$, and retained it until the eleventh Symposium (1966), although it was becoming progressively more complex. In the fifth Symposium (Madrid, 1958), the WHO was represented not only by Dr. Payne but also by the Spaniard Dr. F. Pérez Gallardo, as delegate of the Europe Regional Office ${ }^{79}$.

For the first time, vaccination by attenuated living viruses was one of the key points of the sixth Symposium (1959), in which Albert Sabin spoke on the «Present status of field trials with an oral, live, attenuated poliovirus vaccine» ${ }^{80}$, which was a summary of the article he had published in the JAMA in June of the same year. From the sixth Symposium onwards, we

\footnotetext{
74. European Association against Poliomyelitis, n. 73, p. 7-23.

75. European Association against Poliomyelitis, n. 73, p. 5.

76. The third Symposium also paid considerable attention to the prevention of deformities. See: European Association against Poliomyelitis, n. 73, p. 127-168.

77. European Association against Poliomyelitis. Re-education in walking after Poliomyelitis. IV Symposium, Bologna, 20-22 September 1956. Brussels: EAP; 1957.

78. European Association against Poliomyelitis. Vaccination and immunity. Neurophysiological and neuropathological aspects of poliomyelitis. V Symposium, Madrid, 28-30 September 1958. Brussels: EAP; 1959.

79. European Association against Poliomyelitis, n. 78, p. 3.

80. European Association against Poliomyelitis. Anti-poliomyelitis vaccinations. Physio-Pathology of the respiratory disorder. Poliomyelitis of the «very young child». VI Symposium, Munich, 7-9 September 1959. Brussels: EAP; 1960.
} 
can see the presence of a «Virological Group» as well as an «Orthopaedic Group», together with a more important role for respiratory disorders. These tendencies continued in the seventh (1961) ${ }^{81}$ and eighth (1962) ${ }^{82}$ Symposia, when the different aspects of vaccination and virological problems became the key points, relegating physiological and clinical problems to a secondary role. As we shall see, the importance acquired by virology was also evidenced by the incorporation of Spanish groups from the National Virus Centre, who made some excellent contributions in the eleventh Symposium ${ }^{83}$.

\subsection{Spanish participation}

There was an official Spanish delegation (including Bosch Marín) from the second Symposium onwards. Bosch Marín was elected as one of the Vice-Presidents of the Association at the General Assembly of 1 October 1955. He was chosen as delegate due to his position as Director of Central Services of Infant Hygiene of the General Board of Health of the Interior Ministry. From the fifth until the ninth Symposia, Bosch Marín reported data on poliomyelitis morbidity and mortality in Spain and on the different measures adopted (or rather planned to adopt) in our country against the disease and its after-effects. In the eleventh Symposium (1964), the official Spanish delegation was chosen from among polio experts of the National Virus Centre (Centro Nacional de Virus de Majadahonda) of the General Board of Health. This change showed the importance acquired by experts and virology in the fight against poliomyelitis.

Spanish scientific participation started at the third Symposium (1955) with the neurologist Sales Vázquez and the paediatrician M. de la Iglesia from the Paediatric Clinic of the University of Barcelona, who recounted

81. European Association against Poliomyelitis. Programmes of vaccination. Encephalitis and meningitis in enteroviral infections. Virological and clinical problems. VII Symposium, Oxford, 17-20 September 1961. Brussels: EAP; 1962.

82. European Association against Poliomyelitis. Vaccination and Epidemiology of poliomyelitis and allied diseases. New developments in the programmes of vaccination. Clinical problems. VIII Symposium, Prague, 23-26 September 1962. Brussels: EAP; 1963.

83. European Association against Poliomyelitis. Epidemiology of poliomyelitis in Europe. Problems of vaccinations and virological studies. Surgical treatments and rehabilitation. XI Symposium, Rome, 9-12 October 1966. Brussels: EAP; 1967, p. 102-109. 
their experience with the treatment of poliomyelitis in the acute phase and with hibernation and neuroplegic drugs during the 1954 epidemic in Catalonia ${ }^{84}$. No paper was presented by a Spaniard at the fourth Symposium. Spanish scientific participation took on greater importance at the fifth Symposium in Madrid in 1958. Indeed, as might be expected, this was the Symposium with the greatest Spanish participation, and it was extensively covered by the press, especially the Madrid press ${ }^{85}$. Their contributions centred on the prevention of deformities and different aspects of the rehabilitation of polio victims and were reported with all of the other contributions but in a separate volume ${ }^{86}$. This Symposium was attended by: physicians from the National Hospital for Infectious Diseases, J. Torres Gost, Director, J. Figueroa Egea, Clinical Head and J. Salvia Torres, Intern; traumatologists Bernardo E. Múgica from the Hospital de la Paz (Madrid), Álvaro López Fernández and José E. Bataller Sallée from the National Maritime Sanatorium «La Malvarrosa» (Valencia) and Vicente Sanchis Olmos; surgeons Francisco Martín Lagos, Professor of the Medical Faculty of Madrid and J. Trochuelo Negrete from the Hospital-Asylum of San Rafael; rehabilitation specialists R. Sales Vázquez and C. Ballús Pascual, from the Department of Poliomyelitis Rehabilitation of the Provincial Office of Health, Provincial Clinical Hospital of Barcelona; Heliodoro Ruiz García, Director of the Cabinet of Physical Medicine and Re-education of Madrid; the Paediatric Professor C. Laguna, Member of the Foundation for the Fight against Poliomyelitis and Director of the National School of Puericulture (Madrid); and Dr. Martín Ongil González, Service of General Medicine of the Compulsory Health Insurance of Madrid ${ }^{87}$.

The Sixth Symposium was attended only by the neurologist R. Sales Vázquez and by L. Portal from the Centre for Poliomyelitis Rehabilitation of the Provincial Office of Health, Faculty of Medicine and Clinical Hospital

\footnotetext{
84. European Association against Poliomyelitis, n. 73, p. 116-117.

85. As indicated in another paper, coverage was more exhaustive in the Madrid press than in Valencia: Porras, María-Isabel; Báguena, María-José. La poliomielitis en la España franquista a través de la prensa general (1940-1975). In: Ortiz, Teresa et al., coords., n. 7, p. 324-329.

86. Aportación española al V Symposium europeo sobre poliomielitis. Madrid, 28-30 September 1958. Madrid: Publicaciones «Al servicio del niño español», Ministerio de la Gobernación; 1958.

87. The following doctors from Madrid took part in this Symposium: Doctors Alemany, R. Escudero, F. León, Vicente Giménez, and Luis Gómez Barnuevo.
} 
of Barcelona. The former also took part in the seventh Symposium. There was no Spanish presence in the scientific sessions at either the eighth or ninth Symposia. At the tenth Symposium (1964), Drs. F. Pérez Gallardo, L. Valenciano and J. Gabriel y Galán from the National Virus Centre of Madrid presented the results of the first mass vacination campaign against poliomyelitis with Sabin's oral vaccine, which had taken place between the end of 1963 and the spring of $1964^{88}$. Drs. L. Valenciano, J. Gabriel y Galán and F. Pérez Gallardo from the National Virus Centre of Madrid presented an interesting new study on the epidemiology of poliomyelitis in Spain during 1965 and the first six months of 1966 at the eleventh Symposium (1966) ${ }^{89}$.

Apart from the special case of the fifth Symposium, when there were more Spanish participants from different specialities such as Paediatrics, Rehabilitation, Surgery, and General Practice, the Spanish presence in European Symposia was consistently provided by representatives from Surgery and Rehabilitation and, until the tenth Symposium, from Paediatrics. At that point, the presence of researchers from the National Virus Centre (Majadahonda) led to some extremely modern and professional papers, which were very different from the contributions made by Bosch Marín from the middle of the 1950s until 1963.

\section{Concluding remarks}

Polio, as an important and worrying worldwide problem, was included in the international public health agenda from the 1940s onwards. The main sources for the study of the contents of polio-related international health policies are the World Polio Congresses, the Reports of the Expert Committee on Poliomyelitis of the World Health Organization and the Symposia promoted by the European Association against Poliomyelitis. The International Polio Conferences were funded by the National Foundation of Infantile Paralysis, a very important private organization promoted by President Roosevelt of the USA. In the case of European conferences, they

88. European Association against Poliomyelitis. Reactions and complications after oral vaccination. Problems of the immunity and virological studies. Problems of reeducation. X Symposium, Warsaw, 4-7 October 1964, Brussels: EAP; 1965, p. 91-98.

89. European Association against Poliomyelitis, n. 83, p. 102-109. 
retained the prototype profile of an association of scientists interested in sharing their experiences and research.

The connection of the WHO with European and worldwide initiatives was evident from the very beginning of their operations, which had the support of the WHO. This explains why, despite the diverse origins and aims of the organisations (although they shared the common goal of the highest possible level of international coordination in the struggle against polio), the degree of synergy among them was considerable. Several leading experts were present in the activities of all three, including the virologist Lépine, the epidemiologists Payne and Albert Sabin, and the Spanish epidemiologist and virologist Pérez Gallardo.

Parallel trends can be observed over this period in the topics considered by the three organizations: from general epidemiological aspects at the first meetings, which sought to establish the dimensions of the polio problem worldwide, to updating delegates on virological and immunity research. The number one subject from the mid-1950s was undoubtedly the two aspects of vaccination: 1 ) the debate on the advantages and drawbacks of the two main types: Salk's inactivated polio vaccine (IPV) and Sabin's live attenuated vaccine (OPV), and 2) the experiences of mass immunization with either vaccine in different countries. Other questions, such as treatment in the acute phase, physical therapy, orthopaedic apparatus and rehabilitation from sequelae, also found their place on the agenda of international organisations and meetings.

In terms of Spanish participation in the international arena, Spain was completely absent from the WHO until 1958, although the recommendations of the experts were widely quoted by health authorities and professionals and researchers. Moreover, the organisation did on occasions have delegates acting as advisers in Spain.

In the case of the International and European congresses, there were three types of participation. The first was more political: the primary aim was to win points for an unpopular totalitarian regime in the international community by reporting activities and results that often existed only on paper and did not reflect reality, e.g., on the number of iron lungs in Spain or the number of children vaccinated, very difficult to verify, and on the types of campaign. The second involved paediatricians, orthopaedic experts, and rehabilitation professionals who described their experience in the treatment of polio and its sequelae. Most of these professionals were involved in the implementation of the different services created by the Dirección General de 
Sanidad (General Health Department), the Compulsory Health Insurance Scheme or the hospitals run by religious orders to deal with the problem of polio in Spain. Finally, there was the high-level scientific participation of researchers connected to leading groups in the international arena in the fields of virology and epidemiology, such as the National Virus Centre group or the Sanchis-Bayarri team in Valencia.

The more political profile of the 1940s and 1950s changed from the 1960s onwards, coinciding with the political and social transformations and economic improvements in Spain ${ }^{90}$. It reflected the standards of professional scientists with a prestigious technical profile who announced their results in international forums as experts, ignoring all national political connotations. Without the information which may be provided by ongoing research, we may state that the participation of experts in the international forums studied here may be considered to have a double purpose: support and legitimization of the dictatorial political regime, but also an opportunity for these experts to obtain international backing and recognition, paving the way for them to achieve improvements in their own country. A clear example of this double role was that of Florencio Pérez Gallardo: he served the regime as a member of the official delegation to the Second International Conference (1951) but he also received international recognition, as WHO delegate at the V Symposium (1958) and later as Spanish representative to the European Association against Poliomyelitis, which led to improvements in his Virology Laboratory in the National Health School ${ }^{91}$.

90. On the political, social and economic changes taking place in Spain in the 1960s, see: Moradiellos, Enrique. La España de Franco (1939-1975). Política y sociedad. Madrid: Síntesis; 2003, p. 95-136; Martínez, J., coord. Historia de España siglo XX, 1939-1996. 2ª ed. Madrid: Cátedra; 2003.

91. Ballester; Porras, 2009, n. 7. 